\title{
Influence of the composition and synthesis technology on the physical chemical and performance properties of foam materials
}

\author{
Engel Galimov ${ }^{1, *}$, Nazirya Galimova ${ }^{1}$, Elmira Sharafutdinova ${ }^{1}$, Vladimir Samoylov ${ }^{2}$, and \\ Egor Danilov ${ }^{2}$ \\ ${ }^{1}$ Kazan national research technical university named after A.N. Tupolev, 420111, K Marx St. 10, \\ Kazan, Russia \\ ${ }^{2}$ JSC NIIgrafit, 111524, 2 Elektrodnaya str., Moscow, Russia
}

\begin{abstract}
The comparative analysis of a combination of primary properties of foam materials made using the different starting components and technologies was made. According to the review of the literature and analysis of the experimental data, the paper shows a significant influence the starting components and process approaches have on the properties of the materials. The comparison of material properties revealed that the properties of syntactic carbon foams are higher than those of other porous materials, including metal foams, and comply with the specification.
\end{abstract}

\section{Introduction}

In today's machine building industry, there is an urgent need to develop new, highly chemically and corrosion resistant ultra-high-temperature low-density foam materials with thermophysical properties, most significantly thermal conductivity, controllable in wide ranges. It is known that carbon materials feature a combination of high mechanical properties and comply with the operating conditions of various products and structures in many current manufacturing industries. In terms of potential and efficiency, carbon foams, including syntactic carbon foams, occupy a special place among these materials. The distinctive feature of such foams is a regular structure, the possibility to control density, thermophysical, strength, and many other properties in a wide range by varying raw materials, synthesis and processing methods. Syntactic carbon foams are promising materials for aerospace, machine building, electronics, medicine, and other industries for designing heat sinks and thermal insulation, porous materials with low density, high chemical stability, biological inertness [1].

The earlier papers [2] described the development of the synthesis technologies and studied the performance properties of thermal insulation and thermally conductive syntactic carbon foams with synthetic resins, petroleum and coal tar pitch as binders, microballoons as

\footnotetext{
*Corresponding author: engelgalimov@yandex.ru
} 
fillers, as well as modifying agents. The main purpose of these studies was to develop laboratory technologies for synthesis of thermal insulation and thermally conductive syntactic carbon foams, to prepare for designing the experimental prototype technology for synthesis of foams with a wide range of thermal conductivity and physical mechanical properties to meet the requirements of the specification according to the international agreement "Developing the technology for synthesis of products made from syntactic carbon foams with tailor-made thermophysical properties for extreme applications" [3-5].

\section{Body text}

Tables 1-3 show the comparison of the data of the experimental studies with the data taken from the literature (positions 1-5 correspond to syntactic carbon foams made by the designed technologies, positions 6-12 correspond to carbon and metal foams made using the known technologies [6-9]).

Table 1. Physical properties.

\begin{tabular}{|l|l|l|l|l|}
\hline$\#$ & $\begin{array}{l}\text { Variants of materials and } \\
\text { technologies }\end{array}$ & $\begin{array}{l}\text { Density } \\
\left(\mathrm{g} / \mathrm{cm}^{3}\right)\end{array}$ & Porosity $(\%)$ & $\begin{array}{l}\text { Average cell size } \\
(\mu \mathrm{m})\end{array}$ \\
\hline 1 & $\begin{array}{l}\text { Foams based on carbon } \\
\text { microballoons and phenol } \\
\text { formaldehyde resin }\end{array}$ & $0.07-0.80$ & $64-99$ & $150-300$ \\
\hline 2 & $\begin{array}{l}\text { Foams made by template } \\
\text { carbonization }\end{array}$ & $0.16-0.63$ & $71-93$ & $125-150$ \\
\hline 3 & $\begin{array}{l}\text { Foams based on carbon } \\
\text { microballoons and pitch }\end{array}$ & $0.25-0.67$ & $69.5-89$ & $150-300$ \\
\hline 4 & $\begin{array}{l}\text { Foams made by carbonization under } \\
\text { pressure }\end{array}$ & $0.88-1.08$ & $51-60$ & $250-300$ \\
\hline 5 & $\begin{array}{l}\text { Foams made using a volatile blowing } \\
\text { agent }\end{array}$ & $0.21-0.39$ & $82-91$ & $<0.1 ; 15-20$ \\
\hline 6 & Foam based on P55 carbon fiber & 0.55 & 75 & $250-500$ \\
\hline 7 & Foam based on P120 carbon fiber & 0.55 & 75 & $100-300$ \\
\hline 8 & ORNL's carbon foam & 0.60 & 73 & $200-350$ \\
\hline 9 & $\begin{array}{l}\text { Foam made from AR pitch } \\
\left.\text { (heat treatment } 2800{ }^{\circ} \mathrm{C}\right)\end{array}$ & 0.56 & 75 & $370-520$ \\
\hline 10 & $\begin{array}{l}\text { Graphitized Conoco foam } \\
\left.\text { (heat treatment } 2800{ }^{\circ} \mathrm{C}\right)\end{array}$ & 0.59 & 73 & $400-600$ \\
\hline 11 & Copper foam & 2.25 & 75 & $500-1000$ \\
\hline 12 & Aluminum foam 6061 & 0.50 & 81 & $500-1000$ \\
\hline
\end{tabular}


Table 2. Mechanical properties.

\begin{tabular}{|l|l|l|l|}
\hline$\#$ & Variants of materials and technologies & $\begin{array}{l}\text { Ultimate } \\
\text { compressive } \\
\text { strength (MPa) }\end{array}$ & Hardenss (HV) \\
\hline 1 & $\begin{array}{l}\text { Foams based on carbon microballoons and } \\
\text { phenol formaldehyde resin }\end{array}$ & $5.2-23$ & $14-21$ \\
\hline 2 & Foams made by template carbonization & $5.2-23$ & $15-20$ \\
\hline 3 & Foams based on carbon microballoons and pitch & $9.6-19.2$ & $9-12$ \\
\hline 4 & Foams made by carbonization under pressure & $26-33$ & $7.7-8.5$ \\
\hline 5 & Foams made using a volatile blowing agent & $5.4-12.6$ & $6.5-8.5$ \\
\hline 6 & Foam based on P55 carbon fiber & 15 & - \\
\hline 7 & Foam based on P120 carbon fiber & 25 & - \\
\hline 8 & ORNL's carbon foam & $20-25$ & - \\
\hline 9 & $\begin{array}{l}\text { Foam made from AR pitch } \\
\left.\text { (heat treatment } 2800{ }^{\circ} \mathrm{C}\right)\end{array}$ & 30 & - \\
\hline 10 & $\begin{array}{l}\text { Graphitized Conoco foam } \\
\left.\text { (heat treatment } 2800{ }^{\circ} \mathrm{C}\right)\end{array}$ & 30 & - \\
\hline 11 & Copper foam & 68 & - \\
\hline 12 & Aluminum foam 6061 & 28 & - \\
\hline
\end{tabular}

Table 3. Thermophysical properties.

\begin{tabular}{|l|l|l|l|l|}
\hline$\#$ & $\begin{array}{l}\text { Variants of compositions } \\
\text { and technologies }\end{array}$ & $\begin{array}{l}\text { Thermal } \\
\text { conductivity } \\
{[\mathrm{W} /(\mathrm{m} \cdot \mathrm{K})]}\end{array}$ & $\begin{array}{l}\text { Coefficient } \\
\text { thermal } \\
\text { expansion, } \\
10^{6} \mathrm{~K}^{-1}\end{array}$ & $\begin{array}{l}\text { Thermal stability } \\
\text { in inert atmospheres } \\
\left({ }^{\circ} \mathrm{C}\right)\end{array}$ \\
\hline 1 & $\begin{array}{l}\text { Foams based on carbon } \\
\text { microballoons and } \\
\text { phenol formaldehyde } \\
\text { resin }\end{array}$ & $0.015-2.6$ & $2-3$ & $2750-2890$ \\
\hline 2 & $\begin{array}{l}\text { Foams made by template } \\
\text { carbonization }\end{array}$ & $0.9-3.1$ & $2-4.5$ & $2800-2920$ \\
\hline 3 & $\begin{array}{l}\text { Foams based on carbon } \\
\text { microballoons and pitch }\end{array}$ & $10-50$ & $2.5-4.0$ & $2790-2860$ \\
\hline 4 & $\begin{array}{l}\text { Foams made by } \\
\text { carbonization under } \\
\text { pressure }\end{array}$ & $139.5-162.0$ & $3.1-5.0$ & $>2900$ \\
\hline 5 & $\begin{array}{l}\text { Foams made using a } \\
\text { volatile blowing agent }\end{array}$ & $108-172$ & $2.3-3.5$ & $2820-2880$ \\
\hline 6 & $\begin{array}{l}\text { Foam based on } \\
\text { P55 carbon fiber }\end{array}$ & 12 & - & - \\
\hline 7 & $\begin{array}{l}\text { Foam based on } \\
\text { P120 carbon fiber }\end{array}$ & 60 & - & - \\
\hline 8 & ORNL's carbon foam & 180 & - & - \\
\hline 9 & $\begin{array}{l}\text { Foam made from } \\
\text { AR pitch } \\
\text { (heat treatment } \\
\left.2800{ }^{\circ} \mathrm{C}\right)\end{array}$ & 187 & - & - \\
\hline 10 & $\begin{array}{l}\text { Graphitized Conoco } \\
\text { foam } \\
\text { (heat treatment } \\
\left.2800{ }^{\circ} \mathrm{C}\right)\end{array}$ & 134 & - & - \\
\hline 11 & Copper foam & 40 & - & - \\
\hline 12 & Aluminum foam 6061 & 15 & - & \\
\hline
\end{tabular}




\section{Conclusions}

Therefore, the following conclusions can be made according to the comparative analysis of a combination of primary properties of the foam materials made using different starting components and technologies:

- the operating conditions of synthesis processes have a significant influence on the properties of the materials; and this influence is different for various raw materials; parameters of foam synthesis processes can be used as an effective factor to control their structure and properties; - the comparison of the study results with the literature data shows that the properties of syntactic carbon foams made using the proposed process approaches are similar or significantly higher than those for other foam materials, including aluminum and copper foams.

The work was carried out with the financial support of the Ministry of Education and Science of the Russian Federation within the framework of the Federal Target Program "Research and development in priority areas of development of the scientific and technological complex of Russia for 2014-2020" agreement No. 14.583.21.0057 of July 28, 2016 (Project ID RFMEF158316X0057).

\section{References}

1. I. Michio, Q. Jieshan, G. Quang, Carbon, 87, pp.128-152 (2015)

2. J. Nicholson, Carbon, 11, pp. 65-66 (1973)

3. E.R. Galimov, V.L. Fedyaev, V.M. Samoylov, E.A. Danilov, E.I. Timoshhuk, D.V. Ponomareva, A.V. Nakhodnova, M.A. Orlov, Proc. 8th Int. Sc. and Tech. Conf. Innovative mechanical engineering technologies, equipment, materials, Kazan, pp. 206-212 (2017)

4. E.R. Galimov, D.O. Antonov, E.A. Kashirskaya, Book of abstracts "Gagarin Readings: 43rd Int. Youth Sc. Conf.", Moscow, pp. 374-375 (2017)

5. V.L. Fedyaev, E.R. Galimov, V.M. Samoylov, Proc. 8th Int. Sc. and Tech. Conf. "Innovative mechanical engineering technologies, equipment, materials 2017", Kazan, pp. 347-351 (2017)

6. F.A. Shutov, Syntactic polymer foams, Advances in Polymer Science, 73-74, pp. 63-123 (1986)

7. M. Inagaki, J. Qiu, Q. Guo, Carbon, 87, pp. 128-152 (2015)

8. S.T. Benton, Carbon, 10, pp. 185-190 (1972)

9. E. Bruneton, Carbon, 20, pp. 1919-1927 (2002) 